\title{
A follow-up study of surgery in temporal lobe epilepsy
}

\author{
MURRAY A. FALCONER AND EUSTACE A. SERAFETINIDES \\ From the Guy's-Maudsley Neurosurgical Unit and the Maudsley Hospital, London, S.E.5
}

Since the pioneering work of Wilder Penfield (Penfield and Flanigin, 1950), of Morris (1950), and of Bailey and Gibbs (1951), the surgical possibilities of relieving intractable epilepsy originating in the temporal lobe have interested several neurosurgical centres. In 1955 our own group (Falconer, Hill, Meyer, Mitchell, and Pond) surveyed the literature and presented the results of operation in 30 consecutive patients who had been followed up for periods of from one to four years. A further report on 50 consecutive patients was made in 1958 (Falconer, Hill, Meyer, and Wilson, 1958). In the earlier paper 12 of the 30 patients were reported as apparently free of seizures and 14 others greatly benefited. All but one of these patients had also exhibited a psychiatric disorder pre-operatively, and 20 of these were improved, 17 markedly so. The published results of surgery from other centres at that time were also mentioned. However, it was stated that 'in pioneering any new form of therapy its sponsors must realize that several years must elapse before its merits can be accurately assessed'. We therefore now propose to give such an accounting, and to set out the results of surgery in 100 consecutive patients operated on and followed up for periods ranging from two to 10 years. ${ }^{1}$

\section{CASE MATERIAL}

The criteria used in selecting our material have been outlined in earlier papers (Falconer et al., 1955; Hill, 1958). Briefly they were that the patients were suffering from epilepsy of long standing which had proved resistant to drug therapy; the neuroradiological studies were either normal or showed only slight asymmetries compatible with an atrophic process dating from infancy, e.g., mesial temporal lobe or Ammon's horn sclerosis (Hoare, Falconer,

\footnotetext{
'Two patients have been excluded from this review as they died in the immediate post-operative period and there was thus no opportunity of observing whether the epilepsy would have been relieved or not. One, the second patient submitted to a temporal lobectomy, was mentioned in an earlier paper (1955) and the other, who would have been the 76 th patient, died of an intercurrent acute pulmonary lesion eight days after operation.
}

Kennedy, and Wilson, 1957) but not a spaceoccupying lesion; and E.E.G. studies, repeated several times and employing on at least one occasion sphenoidal electrodes during barbiturate (usually intravenous thiopentone) narcosis, had disclosed a focus of spike discharges confined to or, if bilateral, predominant in the temporal lobe which was subsequently operated upon (Hill, 1953; Pampiglione and Kerridge, 1956; Kennedy and Hill, 1958). Generally the focus was at the sphenoidal electrode. In essence, therefore, these criteria were the frequency and intractability of the seizures, and their localization by electroencephalography. There were only two exceptions as regards the E.E.G. criteria: one patient with a normal E.E.G. but a clinical lateralization and the other with a slow-wave focus. If a focal lesion was demonstrated either radiologically or at operation and was surgically accessible, it was removed by a local excision, generally with relief of the epilepsy, even when the lesion lay outside the electrically firing area (Falconer et al., 1955; Falconer, Driver, and Serafetinides, 1962). Such cases have been excluded from this study. The present series, therefore, consists of cases which fulfilled the above-mentioned criteria, and, as no focal lesion was visible at operation, they were submitted to an anterior temporal lobectomy ranging in extent from 5.5 to $8 \mathrm{~cm}$. (usually $6 \mathrm{~cm}$.) as previously described (Falconer et al., 1955). The series, however, included four patients in whom a small focal lesion was demonstrated radiologically in the depths of the temporal lobe in a site which precluded local excision. The lobe was removed in one piece for detailed pathological siudy, and usually included the uncus, the lateral part of the amygdala, and the anterior 2 to $3 \mathrm{~cm}$. of the hippocampus, as well as the anterior portions of the second and third temporal gyri, the fusiform gyrus, and the hippocampal gyrus. Often most of the superior temporal gyrus (except for its anterior 1 to $2 \mathrm{~cm}$.) was spared to militate against post-operative dysphasia when the dominant lobe was resected, and because experience had shown that little pathological change occurred in it. 
In this respect we differed from Penfield's customary practice (Penfield and Baldwin, 1952).

Since operation all patients have been followed up, usually at frequent intervals in the first year or two, and thereafter annually for periods of from two to 10 years. Most follow-up assessments were made by personal interview at which the patient and a close relative were interviewed separately by both of us. During this interview we first enquired about the frequency of fits, their type, and any medication, and then a physical and psychiatric assessment followed. Most patients were also re-admitted at the end of the first year for detailed E.E.G. and psychological studies. Whenever it was deemed necessary we contacted the referring doctor, and one of us (E.A.S.) or a social worker visited the patient's home. In the few instances where such personal interviews were not possible, the relevant information was kindly given to us by the referring doctor or by post from the patient or his family.

As most of our patients came from the practice of a psychiatric hospital it is inevitable that our material included a large proportion of patients with various psychiatric disorders, including psychosis. In fact only four patients were regarded as mentally normal before operation. In this respect our material differs greatly from that of Penfield (1958) and is probably more in keeping with the series of Bailey and his associates (Bailey and Gibbs, 1951; Bailey, Green, Amador, and Gibbs, 1953; Bailey, 1961) who had their patients referred to them from state mental hospitals. It is also probable that sometimes the presence of a disabling psychiatric disorder influenced the referring doctor to recommend such patients. Further, the criteria for selection were observed somewhat liberally in these cases in the anticipation that any improvement in epilepsy might influence favourably the associated and outstanding psychiatric problem. On the other hand, in cases without severe or with no psychiatric symptoms, there tended to be some reserve in recommending an operation despite the fulfilment of the criteria.

\section{SURVEY OF OPERATIVE RESULTS}

EFFECT ON EPILEPSY In assessing the results of operation we have followed the criteria of Penfield and Steelman (1947) which have since been widely adopted by others (Penfield and Paine, 1955; Picaza and Gumá, 1956; Bloom, Jasper, and Rasmussen, 1960) as well as by ourselves (Falconer et al., 1955) and so have divided our 100 patients into three groups as follows:

Group $A$ (success group) This comprises 53 patients who have become either completely free of seizures after the first year (39 patients) or almost so, i.e., having not more than two or three seizures in any one year (14).

Group $B$ (worthwhile improvement) This group of patients was improved by at least $50 \%$ as regards the number of seizures.

Group C Some of the remaining 17 patients were improved but to a lesser extent.

In making this assessment we disregarded those few patients who, after operation, noticed occasional subjective, aura-like experiences without any impairment of consciousness. Other authors have done likewise.

These results are gratifying considering that preoperatively all these patients had seizures ranging in frequency from a minimum of one a month to several a day, while most of them had suffered for many years. Details of the sex distribution, laterality of the resected temporal lobe, age at onset of epilepsy, age at operation, and pre-operative seizure patterns in each of these three groups are compared in Table $I$. It is evident that there are no significant differences regarding all these variables and the prospects of success. It is probably only chance that more males were operated upon than females, and, as might be expected, there is no statistical significance in the therapeutic results between the two sexes. Again we cannot tell why more left-sided resections were performed than right-sided, especially as in the past two years the proportion in our more recent material has been strikingly reversed. Possibly an explanation for this recent trend is the fact that an auditory learning defect follows removal of the dominant temporal lobe, and there has been such clamour consequently that some physicians may have become chary of referring patients with left-sided foci. However, we feel that apart from exceptional circumstances, such as when a patient is engaged in an academic career, these fears are needless, for few patients ever notice this defect, and those who do learn to compensate for it. Certainly the laterality of the resected temporal lobe does not militate against a good result as regards epilepsy. One patient with bilateral discharges listed as a primary right-sided resection subsequently also underwent a left-sided resection with gross loss of recent memory as has been reported by others (Terzian, 1958). This is our only experience of a bitemporal lobectomy and has already been reported (Falconer et al., 1955).

As in our previous reports a striking feature of our cases is the fact that most patients had had seizures for many years, some even from early childhood, and yet they were not operated upon until adult life. Thus 43 patients dated their seizures from the first decade, including 11 from infancy, and yet only one patient was operated on as a child, and this because 
TABLE I

SEX, LATERALITY OF RESECTED TEMPORAL LOBE, AGE OF ONSET OF EPILEPSY, AGE OF OPERATION, AND PRE-OPERATIVE SEIZURE PATTERNS IN EACH OF THREE GROUPS OF PATIENTS

\begin{tabular}{|c|c|c|c|c|}
\hline Sex & $\begin{array}{l}\text { Group A } \\
\text { (Free or almost free of } \\
\text { seizures) }\end{array}$ & $\begin{array}{l}\text { Group B } \\
\text { (W'orthwhile improvement) }\end{array}$ & $\begin{array}{l}\text { Group C } \\
\text { (Remaining patients) }\end{array}$ & Totals \\
\hline $\begin{array}{l}\text { Male } \\
\text { Female }\end{array}$ & $\begin{array}{l}30 \\
23\end{array}$ & $\begin{array}{r}21 \\
9\end{array}$ & $\begin{array}{l}9 \\
8\end{array}$ & $\begin{array}{l}60 \\
40\end{array}$ \\
\hline $\begin{array}{l}\text { Laterality } \\
\text { Right } \\
\text { Left }\end{array}$ & $\begin{array}{l}22 \\
31\end{array}$ & $\begin{array}{l}14 \\
16\end{array}$ & $\begin{array}{l}8 \\
9\end{array}$ & $\begin{array}{l}44 \\
56\end{array}$ \\
\hline 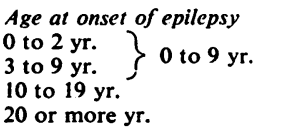 & $\left.\begin{array}{r}4 \\
18\end{array}\right\} \begin{array}{l}22 \\
16 \\
15\end{array}$ & $\left.\begin{array}{r}4 \\
10\end{array}\right\} \begin{array}{r}14 \\
11 \\
5\end{array}$ & $\left.\begin{array}{l}3 \\
4\end{array}\right\} \begin{array}{l}7 \\
6 \\
4\end{array}$ & $\begin{array}{r}11 \\
32\end{array} \begin{array}{r}43 \\
33 \\
24\end{array}$ \\
\hline $\begin{array}{l}\text { Age at operation }(y r .) \\
0 \text { to } 9 \\
10 \text { to } 19 \\
20 \text { to } 29 \\
30 \text { to } 39 \\
40 \text { or more }\end{array}$ & $\begin{array}{r}1 \\
16 \\
19 \\
8 \\
9\end{array}$ & $\begin{array}{r}0 \\
4 \\
10 \\
7 \\
9\end{array}$ & $\begin{array}{l}0 \\
7 \\
5 \\
3 \\
2\end{array}$ & $\begin{array}{r}1 \\
27 \\
34 \\
18 \\
20\end{array}$ \\
\hline $\begin{array}{l}\text { Seizure patterns } \\
\text { Psychomotor alone } \\
\text { Psychomotor and grand mal } \\
\text { Grand mal alone }\end{array}$ & $\begin{array}{r}24 \\
29 \\
0\end{array}$ & $\begin{array}{r}13 \\
15 \\
2\end{array}$ & $\begin{array}{r}5 \\
12 \\
0\end{array}$ & $\begin{array}{r}42 \\
56 \\
2\end{array}$ \\
\hline Totals & 53 & 30 & 17 & 100 \\
\hline
\end{tabular}

TABLE II

RESULTS OF SURGERY FOR EPILEPSY IN RELATION TO PERIOD OF FOLLOW-UP

Duration of Follow-up ( $y r$.
Up to end of second year
3 to 5
6 or more
Totals

Totals

Group A
(Free or almost free of seizures)

Group B

(Worthwhile improvement)

Group C

(Remaining patients)

Totals

$\begin{array}{rr}9 & 4 \\ 16 & 13 \\ 28 & 13 \\ 53 & 30\end{array}$

$\begin{array}{rr}4 & 2 \\ 13 & 7 \\ 13 & 8 \\ 30 & 17\end{array}$

$\begin{array}{rr}2 & 15 \\ 7 & 36 \\ 8 & 49 \\ 17 & 100\end{array}$

she happened to have a small oligoastrocytoma which showed in plain skull radiographs but did not distort the ventricles on air encephalography. Many of our patients were operated on 10 to 20 or even more years after seizures had begun. Only 24 of our patients developed epilepsy after the second decade and could thus be regarded as epileptics of late onset. The oldest patient in the series was 56 years of age, had an unsuspected and indolent oligodendroglioma of the amygdala, and although improved still has some nocturnal attacks seven years later. We have not solved the problem propounded in our earlier paper of localization in cases of presumed temporal lobe epilepsy in childhood, thereby enabling an appropriate operation to be performed with good chances of success while the child is still educable and in the school-going period.

Table I also shows that slightly more than half our patients had grand mal (major convulsions) as well as psychomotor seizures, and that only two patients had grand mal attacks alone. The present data do not indicate that the presence of grand mal as such adversely affects the results, the view previously expressed (Falconer et al., 1955).

A criticism which has been levelled at the surgery of epilepsy in the past has been the inadequacy of the follow-up periods (Meyers, 1954). Our previous reports have been open to this criticism, which time and an adequate follow-up alone can correct. In Table II therefore are set out the latest progress reports of our patients after the first year. Four patients are known to have died between two and five years after operation: one committed suicide and three others died in status epilepticus. All four cases are rated as unimproved (group C). We lost trace at varying intervals after two years of six patients who had gone abroad, and these are listed according to the last available report. The remaining 
patients from the British Isles or overseas have been contacted on the last anniversary of their operation. Table II shows that the long-term results as judged by the follow-up periods of six years or more are as good as the earlier results. Thus the results in 28 of the 52 cases $(54 \%)$ observed for six years or longer remain successful, which is the same proportion for the other groups. Most of these 28 patients have discarded anticonvulsant drugs or for psychological reasons are receiving only 'homeopathic' doses, for it has been our policy to reduce medication after two years in the successfully treated cases. If, however, seizures persist, then medication is continued but often at a reduced level. It therefore appears that, if a successful outcome is apparent at the end of two years, it is likely to persist.

We have chosen the second year as the commencement of our final follow-up studies because 'neighbourhood' fits (to be discussed later as a complication of operation) are common in the first post-operative month and are of no sinister significance, and a few of the patients who have occasional fits in the first year will later become free of fits, and conversely a few who are free of fits during the first year will later develop recurrent seizures. The migration of patients after the first year to their final ratings is shown in Table III. It will be seen that in group A (the success group) only 31 (out of the total of 53) patients were free of fits in the first and subsequent years. Eight patients with fits during the first year subsequently joined this élite group making a total of 39, while 14 entered the category of those who had had only occasional seizures. Again seven patients who were free of fits during the first year subsequently joined group B (worthwhile improvement). Thus, although there may subsequently be a change, the observation that a patient is free of fits during the first year is of some predictive value, for more than three-quarters of such patients will remain free of seizures. Rasmussen and Branch (1962) have made similar observations. However, some of those who continue to have seizures may ultimately join the success or worthwhile groups, although no patient in group $C$ (the failure group) was free of fits during any year.
PSYCHIATRIC CHANGES This aspect has already been discussed in some detail in previous communications but on smaller groups of patients (Falconer et al., 1955; Hill et al., 1957; James, 1960). The present study confirms the view that whenever there is an improvement in epilepsy there is also a corresponding improvement in the concomitant psychiatric disorder. Table IV attempts to assemble the data relating to the present series of cases, which are arranged in the three groups according to the results of operation. As several patients had more than one type of psychiatric disorder, the totals exceed 100 . With each type of psychiatric disorder there is a post-operative rating based upon an arbitrary threepoint scale.

Several points emerge from Table IV. First, the four patients with a normal pre-operative personality remained normal subsequently, even although one of them was only partially relieved of epilepsy. Secondly, only one of the 17 patients not improved or only slightly improved as regards epilepsy (group C) showed an improvement in personality. In this particular patient the improvement was in respect of aggression, and, as has been stressed in previous papers, aggression among the various psychiatric disorders is the feature which above all others is most likely to respond to surgery. Table IV shows, however, that even aggression is only improved provided the epilepsy is also improved. Thirdly, there was no obvious change in the I.Q. of the feeble-minded (I.Q. below 60) patients. On the other hand, some of the patients with inadequate, ineffectual personalities showed an improvement in interpersonal relationships. Fourthly, about half the patients who showed depression pre-operatively were benefited in this respect if the epilepsy was improved. The same can be said of neurotic symptoms. Isolated paranoid features were uncommon.

The psychoses encountered in our patients were of three types, viz., (1) episodic confusional, (2) chronic paranoid, and (3) schizophrenic-like state (Serafetinides and Falconer, 1962). The psychoses of the first group are usually postictal in origin, and respond well if epilepsy is improved. The others do not, particularly the schizophrenic-like states.

TABLE III

APPARENT MIGRATION OF PATIENTS AFTER FIRST YEAR FROM ONE GROUP TO ANOTHER

\begin{tabular}{lccrr} 
& $\begin{array}{l}\text { Group A } \\
\text { (Free or almost free } \\
\text { seizures) }\end{array}$ & $\begin{array}{l}\text { Group B } \\
\text { (Worthwhile improvement) }\end{array}$ & $\begin{array}{l}\text { Group C } \\
\text { (Remaining patients) }\end{array}$ \\
\hline Seizure-free in first year & 31 & 7 & 0 & 38 \\
Some seizures in first year & 22 & 23 & 17 & 62 \\
Number subsequently seizure-free & 39 & 0 & 0 & 0 \\
Number almost seizure-free & 14 & 0 & 17 & 14 \\
Number ultimately placed in group & 53 & 30 & 100
\end{tabular}


TABLE IV

CORRELATION OF CHANGES IN PSYCHIATRIC DISORDERS WITH POST-OPERATIVE IMPROVEMENT IN EPILEPSY

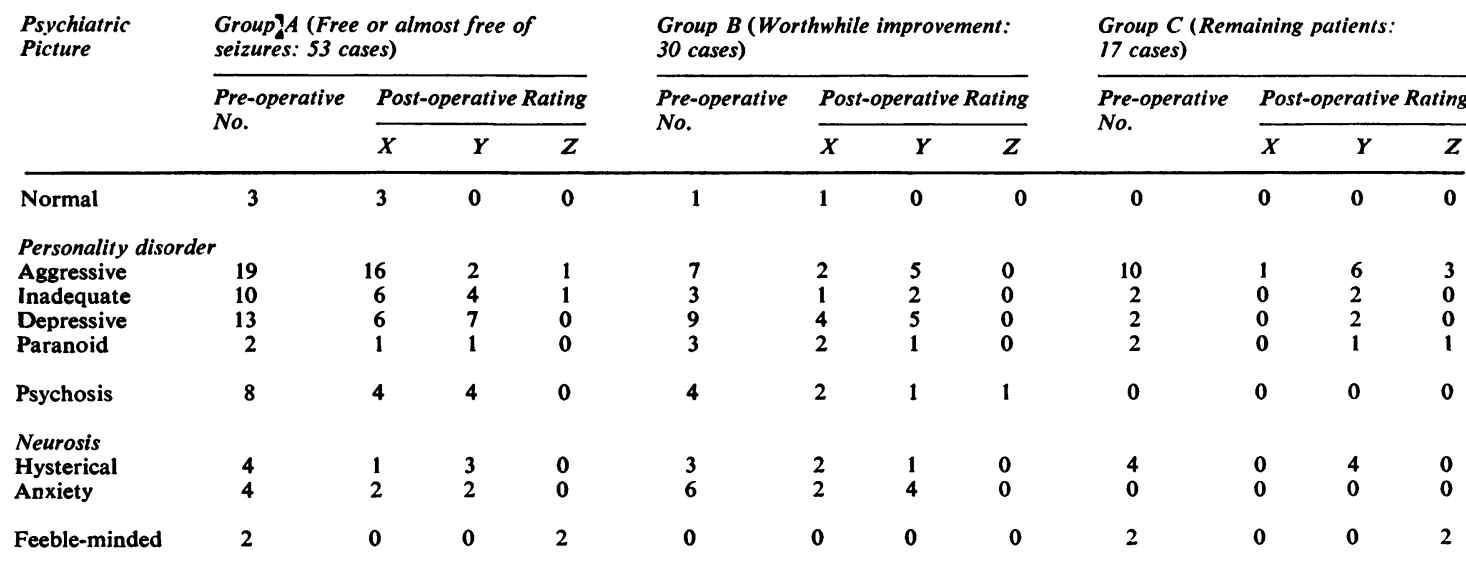

Post-operative psychiatric ratings: $X$ Improved; $Y$ Unchanged; $Z$ Deteriorated.

Table IV, however, does not disclose the important fact which James (1960) has stressed, namely, that the improvement in personality after operation may take a considerable time to manifest itself, even one or two years. During this period of readjustment much pyschotherapeutic support may be required. Patients who before operation were aggressive may after operation go through periods of depression, and some of our patients received electroconvulsive therapy. Vocational guidance is particularly required for those patients who because of epilepsy starting in childhood have never received either a normal education or an adequate training.

POST-OPERATIVE SEQUELAE AND COMPLICATIONS Previous reports from this Unit (Falconer et al., 1955; Meyer, 1959) have listed the usual sequelae of the operation. These include a partial homonymous hemianopia, which in resections of $6 \mathrm{~cm}$. or less is generally slight and affects only part of the upper visual quadrants (Falconer and Wilson, 1958), and, after removal of the dominant temporal lobe, a slight defect of learning by the auditory modality. In practice the latter defect has only very seldom worried our patients who have usually been able to compensate for it. The exception was a telephonist engaged in the routing of long-distance calls; for a time he tried to overcome his disability by jotting down the various telephone numbers, but in the end he changed his job to a clerical one. In a previous paper (Falconer et al., 1955) two other patients who had noticed the defect were mentioned. One was a furniture packer who changed his job because of difficulty in following verbal instructions; he, how- ever, has since returned to his old work. The other was a business man who had found it hard to describe routes through London although he had no difficulty in finding his way either on foot or by motor-car. He is now a director of his company 2 responsible for the employment of heavy building equipment. We could mention yet another patient 8 who is a travel agent fluent in many languages and still manages his work efficiently by making appropriate notes.

However, in addition to these expected sequelae of the operation several post-operative complications were seen in our patients, and these are listed in Table V. In six patients compression caused by an extradural clot resulting in drowsiness necessitated re-opening the craniotomy to remove the clot. All six patients recovered and three of them are in the success group. This complication, therefore, although troublesome at the time, does not militate against a favourable outcome. If, after operation, undue drowsiness or confusion raises the possibility of such a clot, cerebral angiography can usually demonstrate it before operating again.

Forty-five patients had transient 'neighbourhood' fits. These are focal motor seizures involving usually the contralateral face and sometimes even the contralateral arm, often without loss of consciousness. They can occur at any time during the first two weeks after operation, and their frequency ranges widely. They seldom distress the patient physically, although they may upset his morale, and they are usually controlled by anticonvulsant drugs. Occasionally serial attacks of this type occur and require intramuscular paraldehyde or intravenous thio- 
TABLE V

POST-OPERATIVE COMPLICATIONS IN RELATION TO POST-OPERATIVE EPILEPTIC STATE

\begin{tabular}{|c|c|c|c|c|}
\hline & $\begin{array}{l}\text { Group A (Free or almost } \\
\text { free of seizures: } \\
53 \text { cases) }\end{array}$ & $\begin{array}{l}\text { Group B } \\
\text { (Worthwhile improvement: } \\
30 \text { cases) }\end{array}$ & $\begin{array}{l}\text { Group } C \\
\text { (Remaining patients: } \\
17 \text { cases) }\end{array}$ & Totals \\
\hline $\begin{array}{l}\text { Re-opening for clot compression } \\
\text { Transient 'neighbourhood' fits } \\
\text { Transient third nerve paresis }\end{array}$ & $\begin{array}{r}3 \\
19 \\
10\end{array}$ & $\begin{array}{r}2 \\
17 \\
5\end{array}$ & $\begin{array}{l}1 \\
9 \\
0\end{array}$ & $\begin{array}{r}6 \\
45 \\
15\end{array}$ \\
\hline $\begin{array}{l}\text { Hemiparesis } \\
\text { Transient } \\
\text { Persistent }\end{array}$ & $\begin{array}{l}1 \\
2\end{array}$ & $\begin{array}{l}3 \\
1\end{array}$ & $\begin{array}{l}2 \\
0\end{array}$ & $\begin{array}{l}6 \\
3\end{array}$ \\
\hline Complete hemianopia & 8 & 2 & 4 & 14 \\
\hline $\begin{array}{l}\text { Post-operative dysphasia } \\
\text { Transient } \\
\text { Slight persistent }\end{array}$ & $\begin{array}{r}10 \\
2\end{array}$ & $\begin{array}{r}11 \\
1\end{array}$ & $\begin{array}{l}3 \\
2\end{array}$ & $\begin{array}{r}24 \\
5\end{array}$ \\
\hline $\begin{array}{l}\text { Psychiatric } \\
\text { Depression } \\
\text { Confusion } \\
\text { Others }\end{array}$ & $\begin{array}{l}4 \\
2 \\
0\end{array}$ & $\begin{array}{l}\mathbf{2} \\
\mathbf{0} \\
\mathbf{3}\end{array}$ & $\begin{array}{l}2 \\
2 \\
0\end{array}$ & $\begin{array}{l}8 \\
4 \\
3\end{array}$ \\
\hline Uncomplicated & 13 & 4 & 4 & 21 \\
\hline
\end{tabular}

pentone to arrest them. As Table V shows, like compression caused by clot they do not necessarily incur a bad prognosis, for 19 of the 45 patients finished in our success group. In this respect they correspond to fits that occur shortly after head injury. We, however, warn patients before operation of their likelihood, lest they may think the operation has proved unsuccessful. 'Neighbourhood' fits have been described by others (Penfield and Jasper, 1954) and are probably due to transient oedema of the brain spreading from the area of excision.

Several other complications should also be mentioned, most of which like the complications listed above, do not prevent a good result. Transient third nerve palsies were noted in 15 patients and all completely recovered in either a few weeks or months. The mechanism is presumably traction or pressure on the nerve while the uncus is being removed, and is a consequence of the particular operative technique used in this series. Another complication is hemiparesis which occurred in nine of our patients, being transient in six and permanent in three. In some of the transient cases it may well have been a Todd's paresis secondary to neighbourhood fits. In the cases in which it was permanent a different mechanism must have been responsible. This same complication has been recently reported by Penfield, Lende, and Rasmussen (1961) as having occurred in $5 \%$ of their cases being permanent in $2 \frac{1}{2} \%$. Penfield ascribes it to manipulation of the proximal portion of the middle cerebral artery with consequent spasm of the arteries entering the anterior perforated spot. Rasmussen and Branch (1962), by modifying the operation and removing the hippocampus and amygdala piecemeal, aim at avoiding manipulation of the artery and claim that this particular complication can be avoided.

A complete homonymous hemianopia occurred in 14 cases. This subject has already been discussed (Falconer and Wilson, 1958). Sometimes hemianopia followed removals of $8 \mathrm{~cm}$. or more of the temporal lobe, but, on other occasions it followed smaller removals, e.g., $6 \mathrm{~cm}$. There are two possible explanations: there is a great variation in the size and distribution of Meyer's loop of the geniculo-calcarine pathways, or sometimes the posterior cerebral artery may be implicated by spasm. Certainly in our more recent experience in which the resections have not exceeded $6 \mathrm{~cm}$. a minimal homonymous hemianopia affecting only the upper quadrants has been the rule.

A post-operative dysphasia was noted in 29 patients of the the 56 with left-sided resections and was transient in 24 of them. It was always of a nominal type. The mechanism is probably similar to the neighbourhood fits, viz., spreading oedema. In some of the transient instances a post-ictal 'Todd's paresis' mechanism probably also played a part. In five instances it has been persistent, suggesting some involvement of the speech mechanisms in the left posterior temporo-parietal area as described by Penfield and Roberts (1959). It has never been of a degree greater than an inability to name promptly three out of 10 common objects and has usually been less than this. All patients have been able to compensate by paraphrasing. Serafetinides and Falconer (1963) have discussed this phenomenon in greater detail elsewhere.

The psychiatric complications, e.g., psychiatric symptoms appearing either for the first time or as an 
exacerbation of an existing trend, are relatively uncommon, being exhibited by only 15 patients in the whole series. Of these, transient post-operative depression and confusion are the most common and were exhibited by 12 patients, two-thirds of whom were subsequently benefited as regards epilepsy. In groups A and B these features were transient, although, as James (1960) has pointed out, depression may persist for many months, and even warrant electro-convulsive treatment. In the four cases in group $\mathrm{C}$ they have persisted, and two of those patients who showed post-operative confusion have since died, one being our only case of bilateral temporal lobectomy already referred to, and the other a psychopath who died in status epilepticus two years after operation, having been free of fits in the interim period. This patient is the only one in our series who developed the syndrome of loculation of the temporal horn of the lateral ventricle (Cairns, Daniel, Johnson, and Northcroft, 1947). Both patients have already been mentioned (Falconer et al., 1955). Three patients in group B showed other transient psychiatric complications of a paranoid, aggressive, and hypomanic nature respectively.

THE E.E.G. FINDINGS Simultaneously with the improvement in epilepsy there is usually an associated improvement in the E.E.G. tracings, although the relationship is an approximate one. Before operation all but two patients showed spike-discharging foci; one of these had a normal E.E.G. and the other a slow-wave focus. After operation we were able to obtain E.E.G. records approximately one year later. In most instances these were intravenous-thiopentone sphenoidal-electrode studies made by our own colleagues, but in the remaining few they were routine scalp-electrode studies arranged by the patient's doctor. Often we also obtained records three to five years after operation or even later. The results of these studies are set out in Table VI, which shows that normal records were obtained in
61 out of the 100 cases at the end of one year, including 38 of the 53 cases $(71 \%)$ in the success group. By 'normal record' we mean the lack of paroxysmal or epileptic activity. Asymmetries of alpha activity or transient slow activity on the operated side, if present, were not considered as abnormal, as they usually follow temporal lobectomy and they subside in the course of time (Driver and Serafetinides, 1960). A similar proportion of normal records was apparent at the end of three or more years (41 cases out of 65 ). When present the abnormalities usually seen were spike discharges in the opposite temporal lobe, sometimes appearing for the first time, or in the posterior temporal region behind the area of resection. These findings, however, are open to the criticism that almost invariably only a single record was made at the time of followup, and that, if multiple records had been obtained as before operation, a higher proportion of abnormalities would have been disclosed. The present findings, however, indicate a trend, for no single pre-operative record was ever as normal as a normal post-operative one.

As the basis for localizing the side to be operated in almost all our cases was the presence of a spikedischarging focus, which was either strictly unilateral, or, if bilateral, was predominant on the side chosen 2 for surgery, we have studied our cases to see what influence bilaterality of the discharges had on the end-results. In assessing the data (Table VII) ito must be remembered that those cases in which $\overrightarrow{0} \cdot \overrightarrow{0}$ 'epileptic' E.E.G. activity was more or less equal in the two temporal lobes were rejected for operation and are consequently excluded from this assessment, and that in cases with bilateral spikedischarging foci an arbitrary limit of at least four times more epileptic activity on one side was required before operation was considered. We acted on the presumption, which has yet to be proved, that the presence of bilateral epileptic discharges approaching parity suggests that there is no single

TABLE VI

POST-OPERATIVE E.E.G. FINDINGS

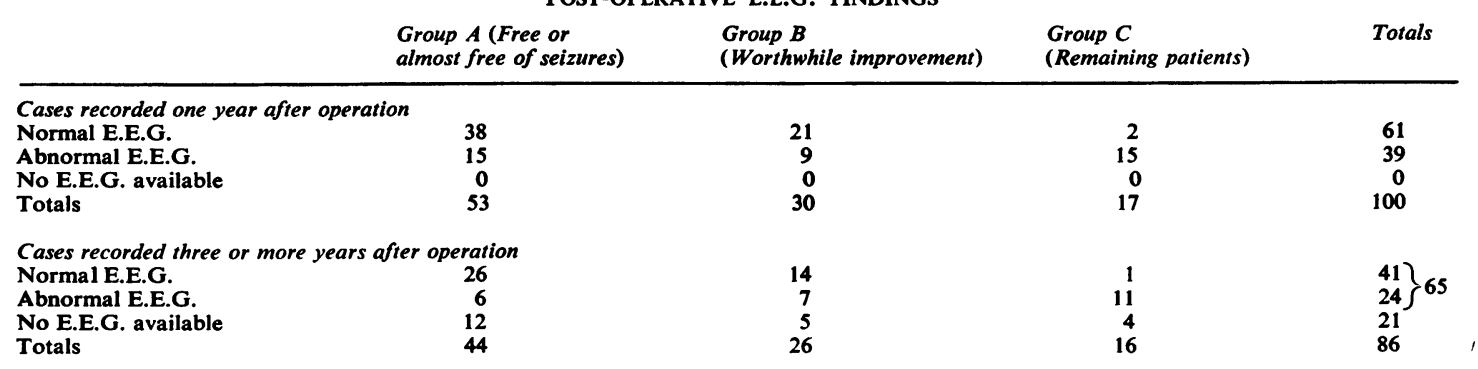

Cases recorded one year after operation

Normal E.E.G.

Abnormal E.E.G.

No E.E.G. available

15

$\mathbf{5 3}$

Group $B$

Orthwhile improvement

Group C 
epileptogenic lesion amenable to surgery, or if there is that it cannot be determined by present methods of investigation.

In an earlier paper from this Unit (Falconer et al., 1955) it was shown that under the conditions of selection just mentioned the presence of bilateral E.E.G. abnormalities only slightly worsened the results. This conclusion is confirmed by our present findings, for in group A (the success group) the ratio of cases with unilateral as opposed to bilateral abnormalities was $3: 2$, whereas in group $C$ (the failure group) the ratio was approximately parity, with group B slightly intermediate. These findings are in keeping with those of Bloom, Jasper, and Rasmussen (1960) who found that when the E.E.G. abnormalities were unilateral two patients out of three were completely or nearly completely relieved; when they were bilateral but predominant to the operated side one out of three was similarly improved; but when the activity was approximately equal only one patient out of 10 obtained benefit. Rasmussen and Branch (1962) have recently reiterated this fact.

An important point to emerge from Table VII is a negative one, viz., that an appreciable number of patients with a strictly unilateral E.E.G. focus (eight out of 56 , or $14 \%$ ) are counted in the group of failures. There is thus a need for a more critical appraisal of the criteria for operation and perhaps also of the operative technique and problems. This aspect of diagnosis will have to be amplified by further experience. It has been the subject of a recent paper by Fényes, Zoltan, and Fényes (1961).

In the present series we have established that the presence of grand mal in addition to psychomotor seizures does not greatly influence results, and neither does the presence of a subsidiary E.E.G. focus in the opposite temporal lobe. However, in the previous paper (Falconer et al., 1955) it was shown that in a small group of five cases in which both factors were present simultaneously the results were bad. In this larger series we endeavoured to see if this still holds true. The relevant data are set out in Table VIII. There were altogether 28 cases with bilateral foci and grand mal, and of these $10(35.5 \%)$ were in the success group, $10(35.5 \%)$ in the worthwhile group, and eight $(29 \%)$ in the failure group. The trend reported earlier is therefore still maintained but our present results are not as pessimistic as was originally forecast (Falconer et al., 1955).

PATHOLOGICAL FINDINGS Our objective in removing the temporal lobe in one piece was to secure pathological material in a suitable state for histological examination. From time to time our colleagues have reported on various aspects of the histological findings (Meyer, Falconer, and Beck, 1954; Meyer and Beck, 1955; Cavanagh and Meyer, 1956; Meyer, 1956 and 1957; Cavanagh, 1958; Cavanagh, Falconer, and Meyer, 1958). These reports have all been on smaller groups of cases.

In Table IX the cases are arranged according to pathological groupings. The first of these groupings, mesial temporal lobe sclerosis, includes all cases with definite sclerosis of the hippocampus (Ammon's horn) of varying degree which were verified histologically. As the sclerotic process often also involves the amygdala and uncus, and in severe cases the adjacent hippocampal, fusiform, and sometimes other temporal lobe gyri, we have preferred the term 'mesial temporal lobe sclerosis'. It is probably identical with the process which Penfield and his associates have termed 'incisural sclerosis' (Earle, Baldwin, and Penfield, 1953) which they however,

TABLE VII

CORRELATION OF PRE-OPERATIVE E.E.G. WITH OPERATIVE RESULTS

\begin{tabular}{lcccc} 
E.E.G. Focus & $\begin{array}{c}\text { Group A (Free or } \\
\text { almost free of seizures) }\end{array}$ & $\begin{array}{c}\text { Group B } \\
\text { (Worthwhile improvement) }\end{array}$ & $\begin{array}{c}\text { Group C } \\
\text { (Remaining patients) }\end{array}$ \\
\hline Unilateral & 32 & 16 & 8 & Totals \\
Bilateral but predominant on operated side & 20 & 14 & 9 & 56 \\
Normal & 1 & 0 & 0 & 17 \\
Totals & 53 & 30 & 17
\end{tabular}

TABLE VIII

CORRELATION OF PRE-OPERATIVE E.E.G. FOCUS AND GRAND MAL WITH OPERATIVE RESULTS

\begin{tabular}{|c|c|c|c|c|c|c|}
\hline \multirow[t]{2}{*}{ E.E.G. Focus } & \multicolumn{2}{|c|}{$\begin{array}{l}\text { Group A } \\
\text { (Free or almost free of seizures) }\end{array}$} & \multicolumn{2}{|c|}{$\begin{array}{l}\text { Group B } \\
\text { (Worthwhile improvement) }\end{array}$} & \multicolumn{2}{|c|}{$\begin{array}{l}\text { Group C } \\
\text { (Remaining patients) }\end{array}$} \\
\hline & Grand Mal & No Grand Mal & Grand Mal & No Grand Mal & Grand Mal & No Grand Mal \\
\hline $\begin{array}{l}\text { Unilateral } \\
\text { Bilateral } \\
\text { Normal } \\
\text { Totals }\end{array}$ & $\begin{array}{r}18 \\
10 \\
1\end{array}$ & $\begin{array}{r}14 \\
10 \\
0\end{array}$ & $\begin{array}{r}7 \\
10 \\
0\end{array}$ & $\begin{array}{l}9 \\
4 \\
0\end{array}$ & $\begin{array}{l}4 \\
8 \\
0\end{array}$ & $\begin{array}{l}4 \\
1 \\
0\end{array}$ \\
\hline
\end{tabular}


TABLE IX

\begin{tabular}{|c|c|c|c|c|}
\hline \multicolumn{5}{|c|}{$\begin{array}{ll}\text { PATHOLOGICAL FINDINGS }\end{array}$} \\
\hline & $\begin{array}{l}\text { Group } A \text { (Free or } \\
\text { almost free of seizures: } \\
53 \text { cases) }\end{array}$ & $\begin{array}{l}\text { Group B } \\
\text { (Worthwhile improvement: } \\
30 \text { cases) }\end{array}$ & $\begin{array}{l}\text { Group } C \\
\text { (Remaining patients: } \\
17 \text { patients) }\end{array}$ & Totals \\
\hline $\begin{array}{l}\text { Mesial temporal lobe sclerosis } \\
\text { Small focal tumours or angiomas } \\
\text { Miscellaneous lesions (scars, infarcts, etc.) } \\
\text { Equivocal changes } \\
\text { Totals }\end{array}$ & $\begin{array}{c}28 \\
14^{1} \\
7^{2} \\
8 \\
53\end{array}$ & $\begin{array}{c}15 \\
8^{3} \\
3 \\
6 \\
30\end{array}$ & $\begin{array}{r}4 \\
2 \\
3 \\
8 \\
17\end{array}$ & $\begin{array}{l}47 \\
24^{193} \\
13^{2} \\
22 \\
100\end{array}$ \\
\hline
\end{tabular}

'Includes one patient with mesial temporal lobe sclerosis.

${ }^{2}$ Includes three patients who also had mesial temporal lobe sclerosis.

${ }^{3}$ Includes two patients who also had mesial temporal lobe sclerosis.

ascribe exclusively to birth injury, a view which we cannot wholly accept. The second group of small focal tumours and angiomas has already been considered in some detail by Cavanagh (1958) and by Falconer and Cavanagh (1959). They are small chronic lesions of which the components are generally glial; their true nature is not yet established. Although some appear to be indolent neoplasms others may be malformations. Clinically they behave as benign lesions. The miscellaneous group includes some small cortical scars thought to be possibly post-traumatic in origin, and some small chronic cortical infarcts secondary to arterial degeneration. The equivocal cases are a further miscellaneous group; some of them had definite leptomeningeal thickening and subpial gliosis, but as there was no definite neuronal loss in the resected specimen, they have been grouped separately. Six patients, three in the group of small focal lesions and three with miscellaneous lesions, also had mesial temporal lobe sclerosis, thus having a dual pathology.

From Table IX it can be seen that nearly half of our cases had mesial temporal lobe sclerosis and nearly a quarter small focal tumours or angiomas. By far the best therapeutic results occurred in these two pathological groups, for out of the 66 cases no fewer than $41(62 \%)$ were in the success group, whereas $11(32 \%)$ were unsatisfactory. Thus the finding of a lesion in the resected specimen, even although this lesion is not visible on the surface at operation, but is found only after careful histological examination, improves the prospects of operation.

\section{DISCUSSION}

The long-term results in the present series show that surgery has a promising, and indeed often rewarding, place in the treatment of intractable temporal lobe epilepsy, but that there are still many factors, such as the criteria for selection of cases, the postoperative management, and even matters of surgical technique, which require re-appraisal and perhaps revision. Eighty-three of our patients were benefited as regards epilepsy, 53 strikingly so, and only 17 can be counted as failures. There are, however, many challenges, not the least of which is that epilepsy is common $(0.4$ to $0.5 \%$ of population according to a report by the College of General Practitioners, 1960), while only a very small minority of patients who are not amenable to drug therapy so far fulfil our criteria for recommending operation.

The development of surgery in temporal lobe epilepsy has been reviewed by several authors (Penfield and Flanigin, 1950; Bailey and Gibbs 1951; Bailey, 1961; Fényes, Zoltan, and Fényes 1961; Rasmussen and Branch, 1962). The origina papers of Penfield reported the effects of superficią temporal cortical ablations, and it was not unti later that he (Penfield and Jasper, 1954) recomo mended the routine removal of the deeper structures including the uncus, amygdala, and anterior hippo campal region. This view as to the extent of the operation has been endorsed by Morris (1956), Picaza and Gumá (1956), and Fényes, Zoltan, and Fényes (1961). Bailey (1961) appears to have removed most of the deeper structures but to have left the hippocampus in situ. Our own particular contribution has been to remove the temporal lobe together with these deeper structures as far as possible in one piece (Falconer, 1953; Falconer et al., 1955) in order to accumulate pathological material suitable for study regarding aetiology and other factors. We do not yet know whether it is necessary to excise routinely this amount of brain tissue, although this is being increasingly recommended (Penfield and Jasper, 1954; Morris, 1956; Picaza and Gumá, 1956; Fényes, Zoltan, and Fényes, 1961). Certainly removal of only the superficial temporal gyri is inadequate (Picaza and Gumá, 1956). More recently Rasmussen and Jasper (1958) have expressed some reluctance to include the hippocampal area, unless there are electrocorticographic indications, on the grounds that memory defects may be incurred. Lastly, operations limited to the mesial structures, as in the "transventricular amygdala-hippocampectomy' described by Niemeyer (1958), have proved 
disappointing when followed up (personal communication, 1959).

The results of surgery in most of the published series followed up for a reasonable period of time have been remarkably consistent. Penfield and Paine (1955) reported that in a series of 68 patients submitted to a temporal lobectomy between the years 1945 and 1950, and subsequently followed for from one to seven years there were 32 patients $(47 \%)$ in the 'success' group and the remaining cases included some with worthwhile improvement. They stress that seizures are most likely to recur during the first six months after operation. Morris (1956), who reported 36 patients followed for from three to nine years, observed a $75 \%$ success rate. Bailey (1961), who followed 60 (out of a total of 72 patients) for a minimum of five years, despite the difficulties of post-operative assessment in his material, including the unreliability of his patients' statements, reported that 18 patients $(30 \%)$ were greatly improved as regards psychomotor seizures and $28(56 \%)$ as regards grand mal. Fényes, Zoltan, and Fényes (1961), who followed a group of 34 patients for from two to five years, reported that good results were observed in 19 patients or $56 \%$ (eight cured and 11 definitely improved) whereas the remaining patients were classified as poor. Rasmussen and Branch (1962) have recently reported that in a grand total of 389 patients submitted to an anterior temporal lobectomy at the Montreal Neurological Institute and followed up for periods ranging from one to 25 years (average five years) $43 \%$ came within the 'success' group. It is, however, difficult, if not impossible, to compare one published series of surgical results with another (especially when followup periods differ, or are made only by correspondence) but the above mentioned results based upon slightly dissimilar assessments may be considered representative of the possibilities of surgery in intractable chronic epileptics.

In all the above series the ultimate selection as to which side should be operated upon appears to have been based on pre-operative E.E.G. findings. Fényes, Zoltan, and Fényes (1961), who included many cases with bilateral temporal lobe disturbances, appear to have based their selection upon 'asymmetries' in the E.E.G. findings rather than upon any preponderance of spike-discharging foci. They report a poor correlation between the pre-operative (and also indeed the post-operative E.E.G. findings) and the therapeutic results, and they stress that some patients with seemingly sparse E.E.G. data pre-operatively attained good therapeutic results and vice versa. They argue therefore that patients who are disabled by epilepsy should be given the benefit of any doubt, for such patients may be improved through operation or at any rate not worsened. However, we would rather agree with Jasper, Arfel-Cardeville, and Rasmussen (1961) that, although there are inconsistencies between the pre-operative E.E.G. findings and the post-operative results, in general the former are of prognostic value. In assessing a case for operation we now link the E.E.G. data with other diagnostic criteria, such as minor asymmetries in the skull or air encephalograms, and with any clinical features of the seizure patterns, such as ictal dysphasia or ictal speech automatisms, which may have some lateralizing value (Serafetinides and Falconer, 1963).

That the E.E.G. criteria which we have employed have some value notwithstanding their limitations is shown by the high incidence of pathological changes found in our surgical material. Mesial temporal lobe sclerosis (Ammon's horn, hippocampus, and amygdala) is the commonest finding (47 out of 100 cases) and it is of interest that our colleagues, Corsellis and Margerison, are observing this same lesion in approximately half the necropsy studies which they are making in patients dying in hospitals for chronic epileptics and diagnosed clinically and electrically as temporal lobe epileptics (personal communication). In a later paper we shall endeavour to show that this lesion usually dates from infancy or early childhood. Coresellis and Margerison so far have not found small focal indolent glial tumours similar to those in our material. It is interesting that in only three patients in this series were there scars compatible with a head injury, and two of these who were benefited also had mesial temporal lobe sclerosis, while the third patient with only a superficial cortical scar in the specimen was not. Traumatic scars, therefore, were an unimportant factor in the production of epilepsy in our cases. Finally, while we are still dealing with the pathological aspects we must remember that of the 22 cases with varying grades of equivocal change, such as leptomeningeal thickening and subpial gliosis, the degree of which is often a matter of personal opinion, no fewer than eight patients (36\%) were strikingly improved. It is possible that in these cases our operation acted by interrupting neuronal circuits concerned with the propagation of seizure discharges, a view put forward earlier by our group (Falconer et al., 1958) and recently stated again by Fényes, Zoltan, and Fényes (1961).

In the group of eight patients who preoperatively showed a seemingly propitious E.E.G. focus but nonetheless were failures, we sought for any factors which might account for the lack of success. As regards pathological findings only one had mesial temporal sclerosis; three showed unsuspected focal lesions of a type which could be multiple (cysticerosis 
one, glial 'hamartomas' two), two showed meningocortical cicatrices; and two equivocal changes. No fewer than six of these patients had a history of head injury, which in five antedated the epilepsy. It is possible therefore that in many of these eight cases there were epileptogenic lesions outside the resected temporal lobe. This contention, which is of course conjectural, is compatible with the observation that one year after operation the E.E.G. findings were abnormal in all eight cases. In four cases there were spike-discharges posterior to the site of operation, in two others at the opposite sphenoidal electrode (one of these also had spikes on the operated side), and in the remaining two there was generalized, high-voltage, intermediate slow activity. Two cases ultimately had normal E.E.G.s five and three years later, and it is noteworthy that these were the two patients who had not had a head injury. One of these two patients was the single instance of mesial temporal lobe sclerosis mentioned above; we have no satisfactory hypothesis to explain this particular failure.

In view of the fact that our best results occurred most consistently in cases with either mesial temporal lobe sclerosis or small focal 'tumours' while our less successful results occurred in cases with miscellaneous or equivocal lesions, we suppose that it was the removal of diseased brain tissue rather than the interruption of neuronal circuits which was the principal factor governing success, although both factors probably operated. Naturally after every temporal lobectomy there is an inevitable glial scar at the plane of resection. The surgery of posttraumatic epilepsy has been founded on the premise that a better scar is substituted for the scar that was there before (Meyers, 1954). Yet we must remember that even a surgical scar may become epileptogenic. Thus Penfield and Erickson (1941) reported that 19 out of 29 patients $(65 \%)$ with meningiomas and epilepsy continued to exhibit seizures after operation, while nine out of 24 patients $(37 \%)$ with meningiomas, who had not had epilepsy previously, developed seizures after operation, generally within six months. They ascribed such seizures in these two groups of meningiomas to scarring in the tumour bed. As the results of surgery in temporal lobe epilepsy appear superior to these results, it may well be the consequence of our having removed the surrounding brain as well as the diseased tissue, so interrupting neuronal circuits involved in the seizure mechanisms. Alternatively some of our failures, especially when the pre-operative findings seemed favourable, may be due to epilepsy arising in the scarred stump.

A high proportion of our cases (43 out of the 100 cases) had epilepsy dating from the first decade of life, and even from infancy, and yet they were not operated on until adolescence or adult life, when the chances of normal schooling had been lost. In later papers we shall show that most of these cases had mesial temporal lobe sclerosis. There are several reasons for the delay, and probably one of the most important is that the E.E.G. abnormalities of childhood differ markedly from those of adults, a topic to which Gibbs (1958) has drawn attention. We have yet to find useful E.E.G. criteria for localizing epileptogenic areas in childhood.

Thus, although the surgery of temporal lobe epilepsy has proved rewarding, there are still many problems confronting it which only time, careful investigation, and the utilization of data obtained from planned experiments can resolve.

\section{SUMMARY}

One hundred consecutive temporal lobe epileptics submitted to an anterior temporal lobectomy have been followed-up for periods ranging from two to 10 years. Of these 53 patients have been rendered free of seizures or almost so, $\mathbf{3 0}$ have been improved at least $50 \%$, and 17 show little or no improvement After the first post-operative year a few patients appear to migrate from one group to another, buf from the second year onwards the ratio of therapeutic results seems constant.

The present study supports the view that, when ever there is an improvement in epilepsy, there is also a corresponding improvement in the concomitant psychiatric disorder.

All but one patient before operation showed E.E.G. evidence of an 'epileptic focus' confined to or predominant in one temporal lobe, and after operation simultaneously with improvement in epilepsy usually the E.E.G. record became normal, although there were exceptions.

Lesions were found in the resected temporal lobe in the great majority of patients. Forty-seven were found to have mesial temporal lobe sclerosis, 24 small 'tumours' or malformations, and miscellaneous or equivocal lesions in the remainder. The results were better in the first two groups.

The limitations of the present criteria for selecting patients for operation are discussed.

This study has been the result of much team work with our various colleagues in the Bethlem-Maudsley and Guy's Hospitals. Thanks are due to all of them for their help and collaboration, and especially to Professor Denis Hill who was the chief collaborator. Financial support was given by the Medical Research Council and from the research funds of Guy's Hospital and of the Bethlem Royal and Maudsley Hospitals. 


\section{REFERENCES}

Bailey, P. (1961). South med. J. (Bgham., Ala.), 54, 299.

-, and Gibbs, F. A. (1951). J. Amer. med. Ass., 145, 365.

-, Green, J. R., Amador, L., and Gibbs, F. A. (1953). Ass. Res. nerv. Dis. Proc., 31, 341.

Bloom, D., Jasper, H., and Rasmussen, T. (1960). Epilepsia (Amst.), 1, 351 .

Cairns, H., Daniel, P., Johnson, R. T., and Northeroft, G. B. (1947). Ser. 14. In Wounds of the Head, edited by H. Cairns, Brit. J. Surg., War Surg Suppl. No. 1, pp. 187-197.

Cavanagh, J. B. (1958). Brain, 81, 389.

-, Falconer, M. A., and Meyer, A. (1958). In Temporal Lobe Epilepsy, edited by M. Baldwin and P. Bailey, p. 140. Thomas, Springfield, Ill.

-, and Meyer, A. (1956). Brit. med. J., 2, 1403.

College of General Practitioners (1960). Brit. med. J., 2, 416.

Driver, M. V., and Serafetinides, E. A. (1960). Electroenceph. clin. Neurophysiol., 12, 758.

Earle, K. M., Baldwin, M., and Penfield, W. (1953). A.M.A. Arch. Neurol. Psychiat., 69, 27.

Falconer, M. A. (1953). Proc. roy. Soc. Med., 46, 971.

- and Cavanagh, J. B. (1959). Brain, 82, 483.

- Driver, M. V., and Serafetinides, E. A. (1962). Ibid., 85, 521. Hill, D., Meyer, A., and Wilson, J. L. (1958). In Temporal Lobe Epilepsy, edited by M. Baldwin and P. Bailey, p. 396. Thomas, Springfield, Ill.

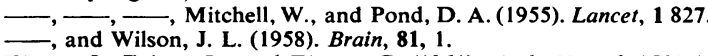

Fényes, I., Zoltan, L., and Fényes, G. (1961). Arch. Neurol. (Chic.). $4,559$.

Gibbs, F. A. (1958). In Temporal Lobe Epilepsy, edited by M. Baldwin and P. Bailey, p. 109. Thomas Springfield, Ill.

Hill, D. (1953). Proc. rov. Soc. Med., 46, 965.

(1958). Ibid., 51, 610 .

- Pond, D. A., Mitchell, W., and Falconer, M. A. (1957). J. ment. Sci., 103, 18.

Hoare, R. D., Falconer, M. A., Kennedy, W. A., and Wilson, J. L. (1957). Excerpta med. (Amst.), Fifth Sympos. Neuroradiol., p. 102 .

James. I. P. (1960). J. ment. Sci., 106, 543.

Jasper, H. H., Arfel-Cardeville, G., and Rasmussen, T. (1961). Ser. IV, Epilepsia (Amst.), 2, 130.
Kennedy, W. A., and Hill, D. (1958). J. Neurol. Neurosurg. Psychiat., 21, 24.

Meyer, A. (1956). Acta neurol. belg., 21, 24.

(1957). In Modern Trends in Neurology (Second Series), edited by D. Williams, p. 301. Butterworth, London.

_-, and Beck, E. (1955). Proc. roy. Soc. Med., $48,457$.

-, Falconer, M. A., and Beck, E. (1954). J. Neurol. Neurosurg. Psychiat., 17, 276.

Meyer, V. (1959). A.M.A. Arch. Neurol. Psychiat., 81, 299.

Meyers, R. (1954). Epilepsia (Boston), Series III, 3, 1.

Morris, A. A. (1950). Med. Ann. D.C., 19, 121.

- (1956). A.M.A. Arch. Neurol. Psychiat., 76, 479.

Niemeyer, P. (1958). In Temporal Lobe Epilepsy, edited by M. Baldwin and P. Bailey, p. 461. Thomas, Springfield, Ill.

Pampiglione, G., and Kerridge, J. (1956). J. Neurol. Neurosurg. Psychiat., 19, 117.

Penfield, (1958). In Temporal Lobe Epilepsy, edited by M. Baldwin and P. Bailey, p. 484. Thomas, Springfield, III.

- and Baldwin, M. (1952). Ann. Surg., 136, 625.

- and Erickson, T. C. (1941). Epilepsy and Cerebral Localization. Thomas, Springfield, IIl.

- , and Flanigin, H. (1950). A.M.A. Arch. Neurol. Psychiat., 64, 491.

- - and Jasper, H. (1954). Epilepsy and the Functional Anatomy of the Human Brain. Churchill, London.

- Lende, R. A., and Rasmussen, T. (1961). J. Neurosurg., 18, 760.

—, and Paine, K. (1955). Canad. med. Ass. J., 73, 515.

- and Roberts, L. (1959). Speech and Brain-Mechanisms. Oxford University Press, London. Princeton University Press, Princeton, N. J.

- , and Steelman, H. (1947). Ann. Surg., 126, 740.

Picaza, J. A., and Gumá, J. (1956). A.M.A. Arch. Neurol. Psychiat., $75,57$.

Rasmussen. T., and Branch, C. (1962). Postgrad. Med., 31, 9.

-, and Jasper, H. (1958). In Temporal Lobe Epilepsy, edited by M. Baldwin and P. Bailey, p. 440. Thomas, Springfield, III.

Serafetinides, E. A., and Falconer, M. A. (1962). J. ment. Sci., 108, 584.

- (1963). Brain, in press.

Terzian, H. (1958). In Temporal Lobe Epilepsy, edited by M. Baldwin and P. Bailey, p. 510. Thomas, Springfield, III. 